\title{
PENERAPAN MODEL PEMBELAJARAN KOOPERATIF TIPE STUDENT TEAM ACHIEVEMENT DIVISION (STAD) BERBANTUAN MEDIA KONKRET UNTUK MENINGKATKAN HASIL BELAJAR MATEMATIKA
}

\author{
Putu Arik Indah Pertiwi \\ Jurusan Pendidikan Guru Sekolah Dasar \\ Universitas Pendidikan Ganesha \\ Singaraja, Indonesia \\ e-mail: arik.indah@rocketmail.com
}

\begin{abstract}
Abstrak
Penelitian ini bertujuan untuk meningkatkan hasil belajar pada muatan pembelajaran Matematika dengan menerapkan model pembelajaran STAD pada siswa kelas IIIA semester II di SDN4 Kampung Baru tahun pelajaran 2017/2018. Jenis penelitian ini adalah penelitian tindakan kelas (PTK), yang terdiri dari 2 (dua) siklus dengan alur penyusunan yakni; perencanaan tindakan, pelaksanaan tindakan, evaluasi, dan refleksi. Pelaksanaan tindakan tiap siklus adalah dua kali pertemuan. Subjek penelitian ini adalah siswa kelas IIIA tahun pelajaran 2017/2018 di SDN 4 Kampung Baru, yang berjumlah 25 orang, sedangkan objek penelitian ini adalah peningkatan hasil belajar pada muatan pembelajaran Matematika. Pengumpulan data dalam penelitian ini dilakukan dengan metode tes. Instrumen yang digunakan adalah lembar tes. Hasil penelitian menunjukkan bahwa terjadi peningkatan hasil belajar Matematika siswa kelas IIIA di SDN 4 Kampung Baru. Berdasarkan tes hasil belajar, pada siklus I rata-rata hasil belajar Matematika siswa diperoleh sebesar 64,48, sedangkan pada siklus II rata-rata hasil belajar siswa mengalami peningkatan menjadi 82,96. Selanjutnya, pada ketuntasan belajar siswa secara klasikal juga terjadi peningkatan, terlihat dari perhitungan ketuntasan belajar klasikal siklus I yakni $40 \%$ dengan kategori sangat rendah dan pada siklus II meningkat menjadi $92 \%$ dengan kategori sangat baik. Hal ini menunjukkan baik dari rata-rata kelas maupun ketuntasan belajar klasikal siswa telah mencapai kriteria ketuntasan yaitu mencapai KKM 75 untuk rata-rata kelas dan mencapai minimal $80 \%$ atau berkategori baik untuk ketuntasan belajar klasikal. Berdasarkan hal tersebut dapat disimpulkan bahwa hasil belajar Matematika dengan menerapkan model pembelajaran STAD pada siswa kelas IIIA SD Negeri 4 Kampung Baru meningkat.
\end{abstract}

Kata kunci: model STAD, hasil belajar matematika.

\begin{abstract}
This study aims to improve learning outcomes on mathematics learning content by applying STAD learning model to third grade students in the second semester of SDN4 Kampung Baru in the 2017/2018 academic year. This type of research is a classroom action research (PTK), which consists of 2 (two) cycles with a drafting path such as; action planning, action execution, evaluation, and reflection. The implementation of the action of each cycle is two meetings. The subjects of this study were the third graders of the 2017/2018 academic year at SDN 4 Kampung Baru, which amounted to 25 people, while the object of this study is the improvement of learning outcomes on the content of learning mathematics. In this research, data collected by test method. The instrument that used in this research is a test sheet. The results showed that there was an increase in Mathematics learning outcomes of third grade students at SDN 4 Kampung Baru. Based on the test of learning outcomes, the average Mathematics learning outcomes students on the first cycle obtained for 64.48 , while in the second cycle the average learning outcomes increased to 82.96. Furthermore, the completeness of student learning is also increased in classical, it's seen from the calculation of classical learning completeness on the first cycle is $40 \%$ with very low category and on the second cycle increased to $92 \%$ with very good category. This shows that the class average as well as the completeness of the classical learning of students has reached the criteria of completeness that reaches KKM 75 for the class average and reaches at least $80 \%$ or categorized well for classical learning completeness. Based on the result of the research, it can be concluded that the learning result of
\end{abstract}


Mathematics by applying STAD learning model to the third grade students of SD Negeri 4 Kampung Baru has increased.

Keywords: STAD learning model, learning result of mathematics

\section{Pendahuluan}

Undang-Undang Nomor 20 Tahun 2003 tentang Sistem Pendidikan Nasional menyebutkan bahwa kurikulum adalah seperangkat rencana dan pengaturan mengenai tujuan, isi, dan bahan pelajaran serta cara yang digunakan sebagai pedoman penyelenggaraan kegiatan pembelajaran untuk mencapai tujuan pendidikan tertentu. Proses pembelajaran harus mempunyai tujuan yang meliputi berbagai aspek yaitu pengetahuan, sikap dan nilai ketrampilan.

Keberhasilan pelaksanaan pembelajaran ditandai dengan tercapainya tujuan pembelajaran serta hasil belajar yang maksimal. Dewasa ini, hasil belajar siswa relatif rendah terutama dalam bidang matematika. Hal ini disebabkan oleh berbagai hal salah satunya yaitu pembelajaran matematika yang dianggap sulit dan menjenuhkan. Matematika sebagai salah satu ilmu dasar, mempunyai peranan penting dalam upaya penguasaan IPTEK karena matematika merupakan sarana yang penting dalam meningkatkan kemampuan dan keterampilan intelektual.Oleh karena itu, guru diharapkan mampu menerapkan berbagai cara dalam menyampaikan materi Matematika agar lebih mudah dimengerti dan bermakna bagi siswa.

Berdasarkan hasil wawancara dengan guru kelas IIIA ditemukan bahwa permasalahan yang dialami guru pada kelas IIIA SD Negeri 4 Kampung Baru adalah sulitnya mengajarkan muatan pelajaran matematika karena guru merasa kurang mampu dalam menguasai konsepkonsep matematika. Hal ini diperkuat dengan hasil observasi yang dilaksanakan di kelas IIIA yang menunjukkan kurangnya motivasi dan keaktifan siswa saat pembelajaran matematika karena guru cenderung menggunakan cara mengajar konvensional dan minimnya media pembelajaran yang digunakan.

Permasalahan-permasalahan tersebut pada akhirnya berdampak pada rendahnya hasil belajar matematika siswa, yakni rata-rata nilai ulangan tengah semester matematika hanya mencapai 60,1, masih di bawah Kriteria Ketuntasan Minimal (KKM) yaitu 75. Hasil belajar matematika siswa kelas IIIA dapat diketahui dari hasil ulangan tengah semester Tahun Pelajaran 2017/2018 semester satu, dari 25 orang siswa terdapat 13 siswa yang belum memenuhi Kriteria Ketuntasan Minimal (KKM) dan hanya 12 siswa yang telah tuntas. Hal ini tentu menjadi tantangan tersendiri bagi guru untuk dapat memperbaiki hasil belajar siswa.

Untuk mengatasi permasalahan di atas, maka akan dilaksanakan suatu penelitian tindakan kelas (PTK) yang berjudul "Penerapan Model Pembelajaran Kooperatif Tipe Student Teams Achievement Division (STAD) Berbantuan Media Konkret untuk Meningkatkan Hasil Belajar MatematikaSiswa Kelas IIIA Semester II SD Negeri 4 Kampung Baru Tahun Pelajaran 2017/2018".

Berdasarkan latar belakang masalah di atas, dapat diidentifikasi masalah yang diajukan pada penelitian ini adalah rendahnya hasil belajar matematika siswa kelas IIIA SD Negeri 4 Kampung Baru dengan rencana pemecahan masalah yaitu penerapan Model Pembelajaran KooperatifTipe Student Team Achievement Division (STAD) berbantuan media konkret. Adapun tujuan penelitian ini adalah untuk mengetahui peningkatan hasil belajar matematika siswa kelas IIIA semester II SD Negeri 4 Kampung Baru Tahun Pelajaran 2017/2018 setelah penerapan model pebelajaran kooperatif tipe Student Team Achievement Division (STAD).

Model pembelajaran kooperatif (cooperative learning) merupakan suatu model pembelajaran yang menggunakan kelompok-kelompok kecil untuk bekerja bersama-sama mencapai tujuan pembelajaran dan beranggotakan 4-6 orang yang heterogen secara akademik, suku, agama, maupun ras. Model pembelajaran ini lebih berorientasi pada keaktifan 
dan kinerja siswa dalam kelompok. Pembelajaran kooperatif mengharuskan siswa bekerjasama untuk mengerjakan tugas atau membuat suatu produk/karya dengan teliti.

Trianto (2007: 41) menyatakan bahwa, "di dalam kelas kooperatif siswa belajar bersama dalam kelompok-kelompok kecil yang terdiri dari 4-6 orang siswa yang sederajat tetapi heterogen, kemampuan, jenis kelamin, suku/ras, dan satu sama lain saling membantu". Setiap siswa diajarkan keterampilan-keterampilan kooperatif agar dapat bekerja sama dengan baik dalam kelompoknya. Keterampilan tersebut seperti, menghargai pendapat teman, berdiskusi dengan teratur, siswa yang pandai membantu yang lebih lemah, dan sebagainya.

Dalam model pembelajaran kooperatif terdapat beberapa variasi model yang dapat diterapkan, salah satunya adalah Model Pembelajaran Student Team Achievement Division (STAD). Pembelajaran kooperatif tipe STAD merupakan salah satu pembelajaran kooperatif yang menggunakan kelompok-kelompok kecil dengan jumlah anggota tiap kelompok 4-5 orang siswa secara heterogen (campuran menurut prestasi, jenis kelamin, dan suku). Secara umum langkah-langkah pembelajarannya diawali dengan penyampaian tujuan pembelajaran, penyampaian materi, kegiatan kelompok, kuis, dan penghargaan kelompok.

Penghargaan atas keberhasilan kelompok dilakukan dengan tahapan-tahapan sebagai berikut: (1) menghitung skor individu, (2) menghitung skor kelompok, dan (3) pemberian hadiah dan pengakuan skor kelompok.Menurut Slavin (dalam Trianto, 2007: 55).

Dalam penerapannya, model pembelajaran tipe STAD akan lebih mudah jika menggunakan media pembelajaran yang mendukung. Media pembelajaran menurut Arsyad (2011: 19) mempunyai tiga fungsi utama apabila digunakan untuk perorangan, kelompok, atau kelompok pendengar yang besar jumlahnya, yaitu; (1) memotivasi manat atau tindakan, (2) menyajikan informasi, (3) memberi instruksi. Secara umum fungsi utama media pembelajaran adalah seebagai alat bantu beajar yang turut mempengaruhi iklim, kondisi, dan lingkungan belajar yang ditata dan yang diciptakan oleh guru.

Arsyad (2011) mengungkapkan bahwa "pemakaian media pembelajaran dalam proses belajar mengajar dapat membangkitkan keinginan dan minat yang baru, membangkitkan motivasi dan rangsangan kegiatan belajar, dan bahkan membawapengaruh-pengaruh psikologis terhadap siswa". Dengan menerapkan strategi dan media pembelajaran yang baikdiharapkan mampu membangkitkan minat dan motivasi peserta didik baik berupa metode maupun pendekatanmelalui alat bantu media dengan berlandaskan fase kegiatan membelajarkan.

Penggunaan media konkret dalam mendukung pembelajaran merupakan salah satu alternatif dalam melatih keterampilan manipulatif siswa dalam indera peraba. Menurut Kurniawan (2011:135) media konkret atau media nyata merupakan media berupa objek sebenarnya dari materi yang dipelajari. Sedangkan, Sudjana dan Rivai (2001:105) menyatakan bahwa media konkret terdiri dari makhluk hidup dan benda tak hidup, sehingga dapat dikatakan media konkret adalah media berupa benda dalam keadaan sebenarnya dan seutuhnya..

Jadi, berdasarkan pendapat yang dikemukakan para ahli tersebut dapat disimpulkan bahwa media konkret adalah suatu media berupa benda dalam keadaan sesungguhnya yang terdiri dari benda hidup maupun tak hidup, yang secara langsung dapat diamati, diraba, diresapi, pada waktu berlangsungnya proses pembelajaran.

Penggunaan media konkret akan sangat membantu siswa sekolah dasar yang menurut teori perkembangan Jean Piaget, siswa usia 7-11 tahun berada pada tahap operasional konkret dimana siswa sangat membutuhkan media konkret untuk dapat memahami apa yang akan dipelajari.

Pembelajaran yang bermankna pada jenjang sekolah dasar akan sangat membutuhkan media dalam penanaman konsep pembelajaran terutama dalam muatan pembeljaran matematika. Seperti mata pelajaran lainnya di lingkungan sekolah dasar, mata pelajaran Matematika juga memiliki hakikatnya sendiri.

Tinggih (dalam Hudojo, 2005) menyampaikan bahwa matematika tidak hanya berhubungan dengan bilangan-bilangan serta operasi-operasi hitungnya semata, melainkan juga berhubungan dengan unsur ruang sebagai sasarannya. Namun penunjukkan kuantitas seperti itu belum memenuhi sasaran Matematika yang lain, yaitu terkait dengan hubungan, 
pola, bentuk, dan struktur. Selain itu, Begle (dalam Hudojo, 2005) mengungkapkan bahwa Matematika tersebut memiliki sasaran atau obyek penelaahan berupa fakta, konsep, operasi, dan prinsip. Sasaran atau obyek penelaahan Matematika tersebut menggunakan simbol-simbol tertentu.

Pembelajaran Matematika di Sekolah Dasar diharapkan dapat terjadi reinvention (penemuan kembali) yaitu menemukan suatu cara penyelesaian secara informal dalam pembelajaran (Heruman, 2008). Walaupun penemuan kembali tersebut merupakan hal yang sederhana, namun bagi siswa Sekolah Dasar penemuan tersebut merupakan sesuatu hal yang baru. Melalui penemuan kembali tersebut, siswa dapat memahami konsep atau materi Matematika yang diajarkan dan dapat menyusun pemahaman dan cara berpikir siswa.

Berhasilnya sebuah pembelajaran matematika terlihat dari proses dan hasil belajar siswa pada saat pembelajaran. Keaktifan siswa dapat dilihat selama proses pembelajaran, namun hasil akhir yang yang menunjukkan pembelajaran matematika telah berhasil terlihat dari hasil belajar matematika siswa. Hasil belajar dapat dijelaskan dengan memahami dua kata yang membentuknya, yaitu "hasil" dan "belajar".

Pengertian hasil (product) menunjuk pada suatu perolehan akibat dilakukannya suatu aktivitas atau proses yang mengakibatkan berubahnya input secara fungsional. (Purwanto, 2009: 44). Hasil belajar seringkali digunakan sebagai ukuran untuk mengetahui seberapa jauh seseorang menguasai bahan yang sudah diajarkan. Untuk mengaktualisasikan hasil belajar tersebut diperlukan serangkaian pengukuran menggunakan alat evaluasi yang baik dan memenuhi syarat. (Purwanto, 2009: 44).

Hasil belajar Matematika yang akan diukur adalah terkait dengan konsep bangun datar dan konsep bangun ruang serta jaring-jaring bangun ruang. Pada penelitian ini, konsep bangun datar diajarkan pada penelitian siklus I, sedangkan konsep bangun ruang serta jaring-jaringnya diajarkan pada penelitian siklus II. Dengan gambaran demikian, dapat mempermudah merancang atau menyusun instrumen yang digunakan dalam mengumpulkan data hasil belajar Matematika.

\section{Metode}

Metode yang digunakan dalam penelitian ini yaitu Penelitian Tindakan Kelas (PTK) karena Penelitian Tindakan Kelas bertujuan untuk mengatasi dan memperbaiki berbagai permasalahan yang terjadi di dalam kelas, yaitu mengenai proses belajar mengajar dan hasil belajar siswa.

Sukarnyana (2006: 10) menyatakan bahwa penelitian tindakan kelas (PTK) merupakan "Penelitian yang memerlukan tindakan untuk menanggulangi masalah dalam bidang pendidikan dan dilaksanakan dalam kawasan kelas atau sekolah dengan tujuan untuk memperbaiki dan atau meningkatkan kualitas pembelajaran".

Dengan melaksanakan tahapan-tahapan dalam PTK, guru mampu memperbaiki proses pembelajaran melalui suatu kajian yang dalam terhadap apa yang terjadi di kelasnya, tindakan yang dilakukan guru semata-mata didasarkan pada masalah yang berkembang di kelasnya (Zainal Aqib, 2006:13-14). Penelitian ini dilaksanakan di kelas IIIA SD Negeri 4 Kampung Baru Kecamatan Buleleng pada bulan April 2018 dengan kegiatan tiap siklus penelitian ini dialokasikan 6 jam pelajaran atau 6 × 35 menit. Subjek dalam penelitian tindakan kelas ini adalah siswa kelas IIIA semester 2 tahun pelajaran 2017/2018 dengan jumlah siswa sebanyak 25 orang. Sedangkan, objek dalam penelitian tindakan kelas ini adalah penerapan model pemebelajaran kooperatif tipe Student Team Achievement Division (STAD) dalam proses pembelajaran matematika.

Penelitian ini dilakasanakan dalam bentuk siklutis, yakni pelaksanaan siklus berikutnya sangat dipegaruhi oleh siklus sebelumnya, dengan kata lain seiap siklus dalam penelitian saling terkait dan berkesinambungan hingga diperoleh hasil yang ingin dicapai.

Setiap siklus dilaksanakan dalam 2 kali pertemuan. Hal ini berdasarkan alokasi waktu muatan pembelajaran Matematika kelas IIIA semester II di SD Negeri 4 Kampung Baru yaitu 4 kali pertemuan dalam 1 minggu untuk satu subtema, masing-masing pertemuan mempunyai 
alokasi waktu $7 \times 35$ menit yang dialokasikan 3x35 menit untuk muatan pembelajaran matematika, serta disesuaikan pula dengan tingkat ketercapaian tujuan yang diharapkan dan rincian indikator yang diteliti. Masing-masing siklus di lakukan dalam 4 tahap yaitu; (1) tahap perencanaan tindakan, (2) tahap pelaksanaan tindakan, (3) tahap evaluasi, dan (4) tahap refleksi.

Adapun langkah-langkah pelaksanaan tindakan dalam penelitian ini dapat dilihat pada gambar berikut.

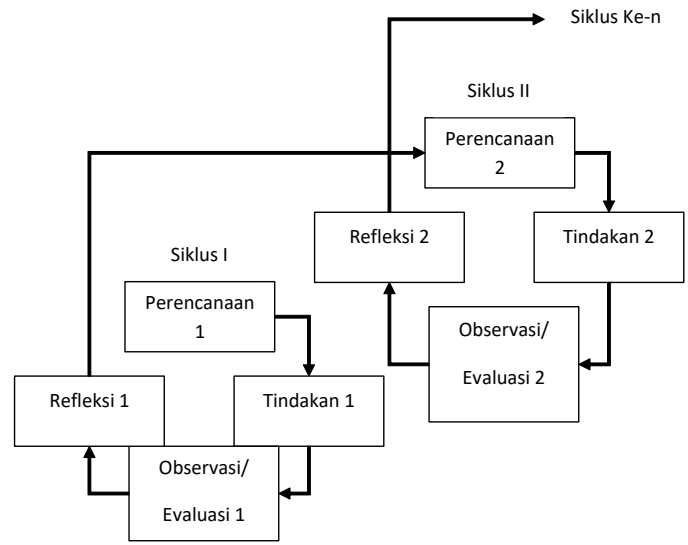

Gambar 1. Rancangan penelitian tindakan kelas yang diaadaptasi dari Kemmis \& McTaggart

Pada siklus I, tahap perencanaan tindakan merupakan tahap awal yang dilakukan peneliti. Kegiatan yang dilakukan pada tahap ini yaitu; (1) menyiapkan materi, (2) membuat RPP, (3) menyiapkan lembar kerja peserta didik, (4) menyiapkan media konkret, (5) menyiapkan soal kuis, dan (6) membuat alat evaluasi berupa soal tes.

Dalam tahap pelaksanaan tindakan, peneliti berperan sebagai pengajar dan pengumpul data. Hal yang dilakukan pada tahap pelaksanaan tindakan ini yaitu melaksanakan kegiatan belajar mengajar di kelas sesuai dengan rencana yang telah dituangkan dalam skenario pembelajaran (RPP). Kegiatan yang dilaksanakan pada tahap ini adalah pelaksanaan tindakan dengan menggunakan Student Team Achievement Division (STAD) pada muatan pelajaran Matematika kelas IIIA SD Negeri 4 Kampung Baru untuk melihat perolehan pemahaman siswa kaitannya dengan pembelajaran.

Tahap evaluasi merupakan tahapan penelitian yang bertujuan untuk menggetahui hasil belajar siswa setelah pelaksanaan pembelajaran. Evaluasi dilakukan setiap akhir siklus. Berdasarkan evaluasi ini, kemudian dapat dipertimbangkan mengenai perlu atau tidaknya pengadaan siklus berikutnya.

Sedangkan, pada tahap refleksi dilakukan pada akhir siklus, pada tahap ini peneliti bersama guru mengkaji pelaksanaan dan hasil yang diperoleh dalam pemberian tindakan tiap siklusnya. Sebagai acuan dalam refleksi ini adalah hasil evaluasi. Hasil ini digunakan sebagai dasar untuk memperbaiki serta menyempurnakan perencanaan dan pelaksanaan tindakan pada siklus selanjutnya.

Langkah-langkah yang dilakukan pada siklus lanjutan atau siklus berikutnya pada prinsipnya sama dengan siklus I, tetapi pada siklus ini bertujuan untuk memperbaiki kekurangan-kekurangan pada tindakan siklus sebelumnya.

Adapun metode pengumpulan data yang digunakan dalam penelitian ini adalah metode tes. Tes merupakan metode yang digunakan untuk mendapatkan data mengenai hasil belajar siswa sehingga dapat diketahui apakah hasil belajar dalam penggunaan metode pembelajaran kooperatif tipe Student Team Achievement Division (STAD), meningkat atau tidak.

Instrument yang digunakan dalam penelitian ini adalah lembar tes evaluasi. Tes evaluasi merupakan lembar soal yang dibuat untuk mendapatkan data tentang hasil belajar matematika siswa. Lembar tes evaluasi dalam penelitian ini berbentuk pilihan ganda sebanyak 10 soal dan uraian sebanyak 5 soal. Pedoman pembuatan tes evaluasi tersebut yakni kisi-kisi soal. 
Setelah seluruh data terkumpul, maka data dianalisis dengan teknik deskriptif kuantitatif dan kualitatif. Menghitung dan menganalisis data penelitian dilakukan dengan menghitung nilai individu terlebih dahulu. Berikut adalah rumus yang digunakan dalam menghitung dan menganalisis nilai individu.

$$
N A=\frac{s p}{S m} \times 100
$$

Keterangan:

$N A=$ Nilai aktivitas

$\mathrm{SP}=$ Skor perolehan

$\mathrm{Sm}=$ Skor maksimal

Untuk memudahkan pengamatan dan proses penilaian rata-rata kelas, maka nilai individu seluruh siswa kelas IIIA dilakukan tabulasi sebagai berikut.

Tabel 1. Tabulasi Nilai Individu Siswa Kelas IIIA

\begin{tabular}{|c|c|c|c|c|c|}
\hline No. & Kode Siswa & $\begin{array}{l}\text { Nilai Akhir per } \\
\text { Siswa }\end{array}$ & $\mathrm{KKM}$ & Keterangan & Kategori \\
\hline \multicolumn{6}{|l|}{1} \\
\hline \multicolumn{6}{|l|}{2} \\
\hline \multicolumn{6}{|l|}{3} \\
\hline \multicolumn{6}{|l|}{4} \\
\hline \multicolumn{6}{|l|}{-} \\
\hline \multicolumn{6}{|l|}{-} \\
\hline \multicolumn{6}{|l|}{25} \\
\hline Jumla & Seluruh Sisn & & & & \\
\hline
\end{tabular}

Setealah menghitung nilai individu, maka dilanjutkan dengan tahap menentukan rata-rata kelas dengan rumus sebagai berikut.

$$
\text { Mean }=\frac{\sum X}{\sum N}
$$

Keterangan:

Mean = rata - rata

$\Sigma \mathrm{X}=$ Jumlah seluruh nilai siswa

$\sum \mathrm{N}=$ Jumlah siswa

Setelah dilakukan penghtungan nilai individu dan rata-rata kelas, maka tahap selanjutnya yaitu menentukan ketuntasan klasikal. Menghitung presentase ketuntasan siswa juga perlu dilakukan dalam penelitian ini, yaitu dengan menggunakan rumus sebagai berikut.

$K B=\frac{P}{n} \times 100 \%$

Keterangan:

$\mathrm{KB}=$ Ketuntasan Belajar

$\mathrm{P} \quad=$ Banyak siswa yang memproleh nilai di atas KKM

$\mathrm{n} \quad=$ Banyak seluruh siswa yang mengikuti tes

Selanjutnya nilai presentase ketuntasan belajar siswa yang di dapat dengan rumus di atas selanjutnya ditafsirkan berdasarkan tabel berikut ini. 
Tabel 2. Kriteria Tingkat Keberhasilan Siswa dalam \%

\begin{tabular}{|c|c|}
\hline Tingkat keberhasilan (\%) & Kategori \\
\hline $90-100$ & Sangat baik \\
\hline $80-89$ & Baik \\
\hline $65-79$ & Cukup \\
\hline $55-64$ & Kurang \\
\hline $0-54$ & Sangat rendah \\
\hline
\end{tabular}

Adapun indikator yang menjadi kriteria keberhasilan dalam penelitian ini adalah penelitian ini dikatakan berhasil jika terjadi peningkatan nilai rata-rata kelas pada muatan pembelajaran matematika yakni mencapai 75 sesuai KKM yang ditentukan oleh sekolah dan terjadi peningkatan ketuntasan belajar pada muatan pembelajaran matematika mencapai minimal $80 \%$ siswa mendapatkan nilai di atas KKM yaitu 75 atau berkategori baik.

\section{Hasil dan Pembahasan}

\section{Hasil Belajar Siklus I}

Data evaluasi siklus I diperoleh dari pemberian soal atau instrumen evaluasi. Evaluasi dilakukan pada akhir siklus, yaitu setelah kegiatan pertemuan kedua. Guru memberikan soal evaluasi dalam bentuk pilihan ganda sebanyak 10 soal, dan 5 soal berbentuk uraian.

Data nilai individu siswa diperoleh berdasarkan perhitungan sesuai dengan rumus analisis data nilai ketuntasan individu yang telah ditentukan. Data nilai individu siswa digunakan sebagai bahan untuk memperoleh data terkait indikator keberhasilan penelitian yakni data ratarata kelas dan data ketuntasan belajar siswa secara klasikal.

Jumlah keseluruhan siswa yang mengikuti tes evaluasi berjumlah 25 siswa dan memperoleh jumlah nilai yakni 1612. Selanjutnya dilakukan perhitungan nilai rata-rata kelas sesuai dengan rumus yang telah ditentukan dan diperoleh data nilai rata-rata kelas siswa pada siklus I yakni 64,48.

Dari keseluruhan siswa yang berjumlah 25 , terdapat 15 siswa yang belum memenuhi KKM yang ditentukan. Artinya, siswa tuntas berjumlah 10 siswa. Maka, berikutnya dilakukan perhitungan terhadap data ketuntasan belajar siswa secara kalasikal sesuai dengan rumus yang telah ditentukan dan diperoleh data ketuntasan hasil belajar siswa secara klasikal yakni $40 \%$ atau berkategori sangat rendah.

Berdasarkan analisis hasil belajar pada siklus I, diperoleh nilai rata-rata kelas siswa kelas IIIA pada muatan pembelajaran matematika mencapai 64,48 dengan kategori sangat rendah. Jika dibandingkan dengan kriteria ketuntasan yaitu 75 , maka nilai rata-rata siklus I masih berada di bawah kriteria keberhasilan penelitian. Jika dilihat dari kriteria ketuntasan belajar secara klasikal yang harus mencapai minimal $80 \%$, maka ketuntasan belajar pada siklus I belum memenuhi kriteria keberhasilan penelitian karena ketuntasan hasil belajar pada siklus I hanya mencapai $40 \%$.

\section{Refleksi Siklus I}

Indikator keberhasilan penelitian mengenai peningkatan rata-rata kelas dan ketuntasan belajar siswa untuk muatan pembelajaran matematika pada siklus I dapat dikatakan belum tercapai. Hal ini disebabkan oleh adanya beberapa kendala pada siklus I yang disebabkan oleh guru dan juga siswa.

Kendala yang disebabkan oleh aktivitas guru anatara lain; pembelajaran masih didominasi oleh guru, guru belum mampu mengelola kelas dengan baik, guru kurang menegaskan aturan dalam kegiatan diskusi kelompok, penyampaian materi oleh guru terlalu cepat, dan guru belum berhasil memberikan motivasi kepada siswa untuk bertanya maupun mengemukakan pendapatnya. Sedangkan kendaala yang dialami dalam aktivitas siswa antara 
lain; siswa masih belum siap mengikuti pembelajaran, masih didominasi oleh siswa dengan kemampuan tinggi di dalam kelompok, siswa belum berani untuk mengajukan pertanyaan atau pendapat, keadaan kelas rebut, kurangnya kepercayaan diri siswa untuk menyajikan hasil diskusi, belum mampu memberikan tanggapan atas kelompok penyaji lain, masih baanyak siswa yang mencontek saat kuis dan evaluasi.

Berdasarkan hasil evaluasi dan kendala-kendala yang dialami pada siklus I, maka penelitian dilanjutkan pada siklus II. Selanjutnya dirancang perbaikan-perbaikan yang dilakukan pada siklus II sehingga kendala-kendala pada siklus I dapat diatasi. Pada siklus II dilakukan perbaikan oleh guru demi tercapainya tujuan pembelajaran serta kriteria ketuntasan yang telah ditetapkan.

\section{Hasil Belajar Siklus II}

Data evaluasi siklus II diperoleh dari pemberian soal atau instrumen evaluasi. Evaluasi dilakukan pada akhir siklus, yaitu setelah kegiatan pertemuan kedua. Guru memberikan soal evaluasi dalam bentuk pilihan ganda sebanyak 10 soal dan 5 soal berbentuk uraian.

Sama halnya dengan siklus I, data nilai individu siswa digunakan sebagai bahan untuk memperoleh data rata-rata kelas dan data ketuntasan belajar siswa secara klasikal. Nilai individu dihitung dengan menggunakan rumus yang telah ditentukan.

Jumlah keseluruhan siswa yang mengikuti tes evaluasi berjumlah 25 siswa dan memperoleh jumlah nilai yakni 2074. Selanjutnya dilakukan perhitungan nilai rata-rata kelas siswa dengan menggunakan rumus yang telah ditentukan dan diperoleh data nilai rata-rata kelas siswa pada siklus II yakni 82,96.

Dari keseluruhan siswa yang berjumlah 25 siswa, terdapat 2 siswa yang belum memenuhi KKM yang ditentukan. Artinya, siswa tuntas berjumlah 23 siswa. Maka berikutnya dapat dilakukan perhitungan terhadap data ketuntasan belajar siswa secara kalasikal dengan menggunakan rumus yang telah ditentukan dan diperoleh data ketuntasan belajar siswa secara klasikal yakni $92 \%$ atau berkategori sangat baik.

Berdasarkan analisis hasil belajar pada siklus II, diperoleh nilai rata-rata kelas siswa kelas IIIA pada muatan pembelajaran matematika mencapai 82,96 dengan kategori sangat baik. Jika dibandingkan dengan kriteria ketuntasan yaitu 75, maka nilai rata-rata siklus II telah memenuhi kriteria keberhasilan penelitian. Jika dilihat dari kriteria ketuntasan belajar secara klasikal yang harus mencapai minimal $80 \%$, maka ketuntasan belajar pada siklus II pun telah memenuhi kriteria keberhasilan penelitian bahkan telah melebihi kriteria minimal yaitu mencapai $92 \%$ dengan kategori sangat baik.

\section{Refleksi Siklus II}

Berdasarkan hasil evaluasi siklus II, menunjukkan bahwa indikator keberhasilan penelitian telah tercapai. Hal ini terlihat dari nilai rata-rata siswa kelas IIIA pada muatan pembelajaran matematika telah mencapai KKM yaitu 75 dan mengalami peningkatan pada ketuntasan secara klasikal yaitu $92 \%$ dengan kategori sangat baik. Dengan demikian penelitian dihentikan sampai siklus II.

Berdasarkan hasil penelitian yang telah diuraikan di atas, dapat ditarik sebuah kesimpulan bahwa penerapan model pembelajaran kooperatif tipe Student Team Achievement Division (STAD) mampu meningkatkan hasil belajar matematika siswa kelas IIIA. Hal ini dapat diketahui dari peningkatan rata-rata kelas dan ketuntasan klasikal siswa.

Berikut merupakan tabel ringkasan hasil evaluasi dalam dua siklus.

Tabel 3. Ringkasan Hasil Evaluasi Siklus I dan Siklus II 


\begin{tabular}{ccccc}
\hline \multirow{2}{*}{ Siklus } & \multicolumn{4}{c}{ Hasil Belajar } \\
\cline { 2 - 5 } & $\begin{array}{c}\text { Jumlah siswa } \\
\text { tuntas }\end{array}$ & $\begin{array}{c}\text { Jumlah siswa } \\
\text { belum tuntas }\end{array}$ & Rata-rata kelas & $\begin{array}{c}\text { Ketuntasan } \\
\text { klasikal }\end{array}$ \\
\hline 1 & 10 & 15 & 64,48 & $40 \%$ \\
\hline 2 & 23 & 2 & 82,96 & $92 \%$ \\
\hline
\end{tabular}

Berdasarkan ringkasan hasil evaluasi siswa, terjadi peningkatan hasil belajar siswa yang dapat dilihat dari hasil evaluasi siswa siklus I dan siklus II. Berdasarkan data yang diperoleh dari siklus I menunjukkan bahwa kriteria keberhasilan yang ditetapkan belum tercapai, karena nilai rata-rata kelas pada muatan pembelajaran matematika belum mencapai KKM yang ditetapkan yaitu 75 dan ketuntasan belajar secara klasikal yang dicapai siswa pada siklus I hanya mencapai $40 \%$ atau berkategori sangat rendah, sedangkan ketuntasan belajar dapat dikatakan tercapai jika nilai rata-rata kelas siswa telah mencapai KKM yang ditetapkan yaitu 75 dan ketuntasan klasikal siswa minimal mencapai $80 \%$ atau berkategori baik. Hal ini disebabkan adanya kendala-kendala dalam pelaksanaan proses pembelajaran yang erat kaitannya dengan penerapan model pembelajaran kooperatif tipe Student Team Achievement Division (STAD).

Berdasarkan pelaksanaan pembelajaran pada siklus I dan II, diketahui beberapa kendalakendala yang terjadi pada tiap siklusnya. Adapun kendala yang dialami pada siklus I, diantaranya kurang maksimalnya pengelolaan kelas oleh guru yaitu pembelajaran masih didominasi oleh guru, sehingga hal ini menyebabkan siswa menjadi pasif. Interaksi guru dan siswa masih kurang, hal ini karena siswa masih malu dan belum mempersiapakan diri untuk mengikuti pembelajaran serta belum beradaptasi dengan guru baru. Disamping itu, sikap individualisme siswa dalam diskusi kelompok masih sangat menonjol, hal ini menyebabkan hanya siswa dengan kemampuan lebih tinggi yang aktif dan sisanya masih belum fokus dalam kegiatan pembelajaran.

Dalam kegiatan diskusi, guru kurang memberikan gambaran yang jelas tentang apa yang harus dilakukan oleh siswa karena guru menduga mereka sudah memahami petunjuk umum yang disampaikan guru. Akibatnya, ada kelompok yang kurang bisa mengerti dalam mengerjakan LKPD. Cara penyampaian guru pada saat memberikan penjelasan mengenai materi maupun arahan pengerjaan tugas kelompok juga terlalu cepat. Di samping itu, guru juga kurang mampu memanajemen waktu untuk tiap-tiap tahap pembelajaran.

Berdasarkan kekurangan-kekurangan tersebut, maka dilakukan tindakan perbaikan yang dilakukan pada siklus II. Adapun tindakan perbaikan yang dilaksanakan, diantaranya memberikan apersepsi dan memotivasi siswa agar tidak malu mengungkapkan pendapat atau pertanyaan kepada guru mengenai hal-hal yang belum dimengerti, melakukan tanya jawab mengenai materi prasyarat dalam pembelajaran dan konsep-konsep penting yang menunjang kegiatan diskusi serta guru melakukan identifikasi permasalahan tiap-tiap kelompok kemudiamn memberikan bimbingan atau penjelasan pada waktu yang bersamaan untuk keseluruhan kelompok, serta menghimbau dan memberikan kesempatan kepada siswa untuk menyimpulkan materi.

Pada siklus II terjadi peningkatan terhadap nilai rata-rata kelas dan ketuntasan belajar siswa secara klasikal pada muatan pembelajaran matematika. Niai rata-rata kelas siswa dalam muatan pembelajaran matematika pada siklus II ini yakni 82,96 dan ketuntasan belajar siswa secara klasikal yakni $92 \%$ dengan kategori sangat baik. Dengan demikian, tujuan yang diinginkan pada indikator ketuntasan sudah tecapai yaitu rata-rata kelas siswa pada muatan pembelajaran matematika telah mencapai KKM yang ditetapkan yakni 75 dan ketuntasan klasikal lebih dari $80 \%$ atau berkategori baik.

Berdasarkan hasil penelitian, model pembelajaran kooperatif tipe Student Team Achievement Division (STAD) ini cocok untuk mengajarkan bidang studi yang sudah terdefinisikan dengan jelas. Hal ini sejalan dengan pendapat para ahli, salah satunya yaitu 
Slavin (dalam Sutirman, 2013:33) menyatakan bahwa, "Gagasan utama dari metode ini adalah untuk memotivasi siswa agar saling membantu satu sama lain dalam menguasai kompetensi yang diajarkan oleh guru".

Pembelajaran dengan menggunakan model pembelajaran kooperatif tipe Student Team Achievement Division (STAD) ini dikembangkan untuk melatih siswa agar dapat bekerja sama dalam kelompok, membantu teman kelompok yang memiliki tingkat prestasi sedang dan rendah agar prestasinya bisa lebih meningkat lagi, sedangkan siswa yang memiliki prestasi tinggi dapat mengasah kemampuan yang dimilikinya untuk dapat berguna bagi orang lain.

Jika siswa menginginkan kelompok memperoleh hadiah, mereka harus membantu teman sekelompok mereka dalam mempelajari pelajaran. Mereka harus mendorong teman sekelompok untuk melakukan yang terbaik, memperlihatkan norma-norma bahwa belajar itu penting, berharga, dan menyenangkan. Kegiatan ini dapat menumbuhkembangkan sikap sosial siswa agar tidak hanya mementingkan kepentingan individu dan mengerti bahwa kegiatan diskusi kelompok adalah kegiatan yang memerlukan kerjasama yang kuat dan dikerjakan secara bersama-sama dengan teman kelompok.

Dengan model pembelajaran ini, siswa yang belum mengerti materi yang dijelaskan diwajibkan untuk bertanya kepada teman kelompoknya yang telah mengerti dan siswa yang ditanyai wajib untuk memberitahu temannya yang bertanya. Guru wajib memastikan bahwa semua anak dalam kelompok masing-masing telah dapat belajar dengan baik dan memastikan semua anak terlibat dalam proses pembelajaran.

Pembelajaran dengan model pembelajaran kooperatif tipe Student Team Achievement Division (STAD) diawali guru menyampaikan tujuan pembelajaran yang ingin dicapai, menjelaskan materi pembelajaran, membagi siswa menjadi kelompok yang beranggotakan 4-5 orang siswa, kemudian kelompok melakukan diskusi kelompok daalam bentuk lembar kerja (LKPD) untuk dikerjakan secara berkelompok sesuai aturan-aturan model pembelajaran kooperatif tipe Student Team Achievement Division (STAD), dimana seluruh siswa harus terlibat dalam diskusi, yang tidak mengerti wajib bertanya dan yang ditanyai wajib memberitahu, hingga presentasi oleh perwakilan tiap-tiap kelompok, mengerjakan kuis kecil yang diberikan guru serta tidak boleh membantu siswa lain dalam mengerjakan kuis, dan diakhiri dengan menarik kesimpulan berdasarkan pembelajaran yang telah dilaksanakan.

Berdasarkan data-data yang diperoleh dari penelitian tersebut, maka dapat disimpulkan bahwa penerapan model pembelajaran kooperatif tipe Student Team Achievement Division $(S T A D)$ dapat meningkatkan hasil belajar pada muatan pembelajaran matematika siswa kelas IIIA semester genap di SD Negeri 4 Kampung Baru tahun pelajaran 2017/2018.

\section{Simpulan dan Saran}

Berdasarkan uraian pada bab IV mengenai hasil dan pembahasan, maka dapat ditarik kesimpulan bahwa Penerapan model pembelajaran kooperatif tipe Student Team Achievement Division (STAD) secara tepat dapat meningkatkan nilai ratai-rata kelas pada muatan pembelajaran Matematika di kelas IIIA SD Negeri 4 Kampung Baru. Hal ini dapat dilihat dari hasil evaluasi siklus I dan II yang dieroleh siswa, yakni dengan perolehan nilai rata-rata 64,48 pada siklus I, kemudian mengalami peningkatan menjadi 79,04 pada siklus II.

Adapun saran yang ingin disampaikan dari hasil penelitian ini antara lain; siswa diharapkan lebih mampu melakukan kerjasana antar anggota kelompok dan tidak mementingkan sikap individualisme dalam diskusi kelompok agar kekompakan antar anggota kelompok dapat terjalin dengan baik, guru diharapkan untuk dapat mengelola kelas dengan lebih maksimal serta menerapkan model pembelajaran kooperatif tipe Student Team Achievement Division (STAD) dalam melaksanakan proses pembelajaran untuk meningkatkan hasil belajar siswa, dan kepada sekolah diharapkan dapat mempertimbangkan penggunakan model pembelajaran kooperatif tipe Student Team Achievement Division (STAD) dalam kegiatan pembelajaran untuk mata pelajaran lainnya sebagai upaya untuk meningkatkan kualitas pendidikan di sekolah. 


\section{Daftar Rujukan}

Agung, A.A. Gede. 2010. Metode Penelitian Pendidikan. Singaraja: Universitas Pendidikan Ganesha.

Anderson dan Krathwohl. 2010. Kerangka Landasan untuk Pembelajaran, Pengajaran, dan Assesmen (Revisi Taksonomi Pendidikan Bloom). Yogyakarta: Pustaka Pelajar.

Aqib, Zainal. 2006. Penelitian Tindakan Kelas untuk Guru. Bandung: Yrama Widya.

Arsyad, Azhar. 2011. Media Pembelajaran. Jakarta: PT Rajagrafindo Persada.

Danim, Sudarwan. 2002. Inovasi Pendidikan dalam Upaya Peningkatan Profesionalisme Tenaga Kependidikan. Bandung: Pustaka Setia.

Daryanto. 2010. Media Pembelajaran Sangat Penting dalam Mencapai Tujuan Pembelajaran. Yogyakarta: Gava Media.

Heruman. 2007. Model Pembelajaran Matematika di Sekolah Dasar. Bandung: PT Remaja Rosdakarya.

Herry, Hermawan, Asep dkk. 2007. Belajar dan Pembelajaran Sekolah Dasar. Bandung: UPI Press.

Hudojo, Herman. 2005. Strategi Belajar Mengajar Matematika. Malang: IKIP Malang.

Kurniasih, Imas dan Berlin Sani. 2014. Implementasi Kurikulum 2013. Surabaya: Kata Pena.

Kurniawan. 2011. Guru Professional. Bandung: Pers.

Mulyatiningsih, Endang. 2009. Metode Penelitian Terapan Bidang Pendidikan. Yogyakarta: Alfabeta Bandung.

Purwanto. 2009. Evaluasi Hasil Belajar. Surakarta: Pustaka Belajar.

Runtukahu, Tombokan dan Kandou, Selpius. 2014. Pembelajaran Matematika Dasar bagi Anak Berkesulitan Belajar. Yogyakarta: Ar-Ruzz Media.

Rusman. 2012. Model-model Pembelajaran Mengembangkan Profesionalisme Guru. Jakarta: PT Rajagrafindo Persada.

Sadiman, Arief S, dkk. 2011. Media Pendidikan. Jakarta: Rajagrafindo Persada.

Sanaky, Hujair. 2009. Media Pembelajaran. Yogyakarta: Safiria Insania Press.

Sudjana, Nana. 1987. Dasar-dasar Proses Belajar Mengajar. Bandung: Sinar Baru Algensindo.

Sudjana Nana dan Rivai Ahmad. 2001. Media Pengajaran. Bandung: Algensindo.

Sudjana, Nana. 2011. Penilaian Hasil Proses Belajar Mengajar. Bandung: PT. Remaja Rosda Karya.

Sudijono, Anas. 2008. Pengantar Statistik Pendidikan. Jakarta: PT RajaGrafindo Persada. 
Sukarnyana, I Wayan dan Kasihani Kasbolah E. S. 2006. Penelitian Tindakan Kelas (PTK). Malang: Universitas Negeri Malang.

Suprijono, Agus. 2009. Cooperative Learning Teori \& Aplikasi PAIKEM. Yogyakarta: Pustaka Pelajar.

Trianto. 2007. Model-model Pembelajaran Inovatif Berorientasi Kontruktivistik. Jakarta: Prestasi Pustaka Publisher.

........ 2009. Model-model Pembelajaran Inovatif Berorientasi Konstruktivistik. Jakarta: Prestasi Pustaka Publisher. 